STAINU Purworejo: Jurnal As Sibyan Jurnal Kajian Kritis Pendidikan Islam

\title{
PENGARUH MINAT MEMBACA SISWA TERHADAP PRESTASI BELAJAR BAHASA INDONESIA SISWA KELAS III MIN 3 PURWOREJO
}

\author{
Indah Sundari, S.Pd \\ STAINU Purworejo \\ Email: sundariindah68@gmail.com \\ Saifudin Zuhri, M.A \\ STAINU Purworejo \\ Email: saifudinzuhrisaja@gmail.com
}

\begin{abstract}
The Influence of Student reading interest on students Indonesian achievement in grade III MIN 3 Purworejo. This research is field research that looks at the problems of reading interest on learning Bahasa Indonesia in grades III at MIN 3 Purworejo with the problems and how students reading interes, how is the achievement of Indonesian students in grade III and is there an effect of reading interest on Indonesian learning achievement achieved by students grade III at MIN 3 Purworejo. Therefore, the writer raised the title "The Influence of reading interest on Indonesian learning achievement of grade III students of MIN 3 Purworejo". This type of research is quantitative research using inferential statistical techniques, namely statistical techniques, namely statistical techniques used to analyze sample data and the results aplly to the population. Research location at MIN 3 Purworejo. Furthermore, the population in this study were all grade III students at MIN 3 Purworejo. Data collection techniques were collected through questionnaires, interviews, and documentation which were then analyzed through parametric statistical statistics with a simple Linear regression formula. Based on the results of research and statistical analysis carried out using a simple linear regression formula, the results of the calculation of Pearson's Product Moment correlation indicate that the statue $=0,828>$ ttabel $=0,297$ with a significant level of 5\% means that reading interest has a strong relationship with Indonesia learning achievement. The result of the ttest calculation shows that thitung = $9,802>$ tabal $=2,000$ with a significance level of 5\%. The result of the calculation of the test Fcount $=96,070$ and Ftabel $=2,2$ with a significant level of 5\% the result of the coefficient $(R 2)=0.686$ whitch show that reading interest affects the Indonesian language learning achievement by $68 \%$ while the other $32 \%$ is influenced by other factors.
\end{abstract}

\section{Keywords: Reading interest, Indonesian language learning, learning achievement.}

\begin{abstract}
Abstrak
Pengaruh Minat Membaca Siswa Terhadap Prestasi Belajar Bahasa Indonesia Siswa Kelas III MIN 3 Purworejo, penelitian ini Pengaruh minat membaca permasalahan bagaimana minat membaca siswa, bagaimana prestasi belajar Bahasa Indonesia siswa kelas III dan adakah pengaruh minat membaca dengan prestasi belajar Bahasa Indonesia yang diraih oleh siswa kelas III di MIN 3 Purworejo. Adapun tujuan penelitian untuk mengetahui bagaimana minat membaca siswa, bagaimana prestasi belajar siswa dan adakah pengaruh minat membaca dengan prestasi belajar bahasa Indonesia yang diraih
\end{abstract}


STAINU Purworejo: Jurnal As Sibyan

Jurnal Kajian Kritis Pendidikan Islam

Vol 4 No 1 Januari - Juni 2021

dan Manajemen Pendidikan Dasar

Homepage: https://ejournal.stainupwr.ac.id/

Email: sibyan.stainupwrj@gmail.com

E-ISSN: : 2599-2732

oleh siswa yang ada di MIN 3 Purworejo. Jenis Penelitian yang digunakan adalah penelitian kuantitatif dengan menggunakan teknik statistik inferensial yaitu teknik statistik yang digunakan untuk menganalisis data sampel dan hasilnya berlaku untuk populasi. Lokasi penelitian di MIN 3 Purworejo. Selanjutnya, populasi pada penelitian ini adalah seluruh siswa kelas III di MIN 3 Purworejo. Teknik pengambilan data dikumpulkan melalui metode angket, wawancara, dan dokumentasi yang selanjutnya dianalisis melalui statistik parametrik dengan rumus regresi linear sederhana. Berdasarkan hasil penelitian dan analisis statistik yang dilakukan dengan menggunakan rumus regresi linear sederhana, maka diperoleh hasil penghitungan korelasi Product Moment Pearson menunjukkan bahwa $r_{\text {hitung }}=0,828>r_{\text {tabel }}=0,297$ dengan taraf signifikan 5\% berarti minat baca memiliki hubungan yang kuat dengan prestasi belajar Bahasa Indonesia. Hasil penghitungan t-test menunjukkan bahwa $t_{\text {hitung }}=9,802>t_{\text {tabel }}=2,000$ dengan taraf signifikansi 5\%. Hasil penghitungan uji $F_{\text {hitung }}=6.070$ dan $F_{\text {tabel }}=2,2$ dengan taraf signifikan 5\%. Hasil koefisien $\left(R^{2}\right)=0,686$ yang menunjukkan bahawa minat membaca berpengaruh terhadap prestasi belajar bahasa Indoensia sebesar 68\% sedangkan 32\% yang lain dipengaruhi oleh faktor yang lain.

\section{Kata Kunci: Minat Membaca, Pembelajaran Bahasa Indonesia, Prestasi Belajar}

\section{A. PENDAHULUAN}

Pendidikan merupakan suatu proses belajar yang berlangsung seumur hidup, maksudnya pendidikan tidak berhenti hingga individu menjadi dewasa dan tetap terus berlangsung sepanjang hidupnya. Dalam pembangunan nasional pendidikan dihadapkan pada tantangan dan perjuangan yang kompleks yaitu untuk menyiapkan sumber daya manusia yang berkualitas, unggul, dan siap berkompetisi dalam menghadapi persaingan di pasar global, salah satu syaratnya adalah dengan memiliki kecerdasan.

Membaca merupakan proses komunikasi. Membaca merupakan sarana hiburan dan sarana menambah wawasan dan pengetahuan. Dengan membaca, seseorang dapat merangsang otaknya untuk berpikir kreatif dan sistematis, memperluas dan memperkaya wawasan, serta dapat membentuk kepribadian yang unggul dan kompetitif. Minat membaca siswa merupakan salah satu indikator kualitas pendidikan formal. Minat membaca berpengaruh terhadap kemampuan siswa dalam menangkap informasi yang tertera dalam bacaan sehingga diharapkan siswa lebih kritis menyikapi berbagai persoalan. Berdasarkan minat membaca akan diketahui pola pikir dan pengetahuan serta wawasan siswa.

Minat membaca siswa merupakan hal yang berpengaruh terhadap proses belajar mengajar disekolah. Minat membaca berkaitan dengan kemampuan 
STAINU Purworejo: Jurnal As Sibyan

Jurnal Kajian Kritis Pendidikan Islam

Vol 4 No 1 Januari - Juni 2021

dan Manajemen Pendidikan Dasar

Homepage: https://ejournal.stainupwr.ac.id/

Email: sibyan.stainupwrj@gmail.com

E-ISSN: : 2599-2732

membaca siswa. Apabila seorang siswa memiliki ketertarikan terhadap hal-hal yang diminati maka ia akan berusaha mencari informasi yang berkaitan dengan ketertarikannya tersebut, baik dengan membaca buku maupun sumber informasi lainnya. Hal tersebut diharapkan dapat memacu siswa untuk membaca, sehingga membaca menjadi suatu kebiasaan. Minat membaca yang didukung dengan kemampuan membaca diharapkan dapat meningkatkan pengetahuan serta wawasan siswa.

Prestasi belajar merupakan hasil belajar yang dicapai setelah melalui proses kegiatan belajar mengajar. Prestasi belajar dapat ditunjukkan melalui nilai yang diberikan oleh seorang guru dari jumlah bidang studi yang telah dipelajari oleh peserta didik. Prestasi belajar tersebut dinyatakan dalam bentuk angka atau symbol seperti yang tertera dalam rapor.

MIN 3 Purworejo adalah sebuah sekolah yang setara dengan Sekolah Dasar terletak di jalan Mentogaten Kidul Rt 01/ Rw 02. Sekolah ini dijadikan sebagai sekolah favorit yang ada di Kecamatan Bayan. MIN merupakan salah satu sekolah pendidikan favorit di Purworejo. Saya tertarik untuk melakukan penelitian minat membaca pada kelas III karena di kelas tersebut, terdapat beberapa siswa yang kurang minat membaca sehingga mempengaruhi prestasi belajarnya. Bahkan ada salah satu siswa kelas III yang belum bisa membaca dengan lancar. Hal-hal yang menjadi penyebab kurangnya minat membaca anak-anak di sekolah ini karena kurang kesadaran dalam diri anak akan pentingnya membaca, dan faktor lingkungan anak seperti teman sebayanya dan situasi serta kondisi lingkungan sekolahnya yang menyebabkan anak memiliki minat membaca yang rendah. Pada saat peneliti melakukan penelitian di MIN 3 Purworejo, ada siswa yang berkunjung ke perpustakaan setiap istirahat, selain itu ada juga siswa yang datang ke perpustakaan saat menerima tugas dari guru dan saat jadwal berkunjung saja. Siswa di kelas tinggi khususnya, sudah ada yang membawa telepon seluler pribadi, sehingga ada siswa yang lebih tertarik untuk bermain dengan game dalam telepon seluler dibandingkan membaca buku. Setelah pulang sekolah, ada siswa yang memilih bermain PS ataupun menonton televisi. Hal itu berakibat kepada 
STAINU Purworejo: Jurnal As Sibyan

Jurnal Kajian Kritis Pendidikan Islam

Vol 4 No 1 Januari - Juni 2021

dan Manajemen Pendidikan Dasar

Homepage: https://ejournal.stainupwr.ac.id/

Email: sibyan.stainupwrj@gmail.com

E-ISSN: : 2599-2732

kemampuan siswa untuk menerima materi pelajaran kurang memuaskan. Banyak siswa yang memperoleh hasil tes harian yang rendah. Bahkan ada siswa yang kadang tidak mengerjakan pekerjaan rumahnya sehingga harus mengerjakannya di luar kelas.

Kebiasaan membaca yang dilakukan oleh seseorang ditentukan oleh berbagai faktor, salah satunya minat. Higard (dalam Slameto, 2013: 57) menyebutkan interest is persisting tendency to pay attention and to enjoy some activity or content. ${ }^{l}$ Minat adalah kecenderungan untuk menaruh perhatian dan menikmati beberapa kegiatan. Minat merupakan faktor internal yang mempengaruhi seseorang untuk berbuat sesuatu, salah satunya membaca. Orang yang memiliki minat dalam kegiatan membaca akan cenderung menyukai dan menaruh perhatiannya pada kegiatan tersebut. Menurut Lilawati (dalam Sudarsana dan Bastiano, 2010: 4,27) minat baca adalah suatu perhatian yang kuat dan mendalam disertai dengan perasaan senang terhadap kegiatan membaca sehingga mengarahkan individu untuk membaca dengan kemauannya sendiri. Minat baca merupakan salah satu kunci penting bagi seseorang untuk memperoleh ilmu pengetahuan dan informasi. ${ }^{2}$

Sekolah Dasar (SD) termasuk bagian dari program wajib belajar Sembilan tahun, dan merupakan lembaga pendidikan pertama yang menekankan siswa untuk belajar membaca, menulis, dan berhitung. Ketrampilan tersebut merupakan landasan dan syarat bagi siswa untuk memperoleh ilmu pengetahuan. Tanpa penguasaan ketrampilan siswa akan mengalami kesulitan untuk menguasai ilmu pengetahuan. Selain penguasaan ketrampilan tersebut, hal yang paling mendasar untuk menguasai sebuah ilmu pengetahuan adalah dengan menguasai bahasa. Menurut BSNP (2006: 119) bahasa memiliki peran sentral dalam perkembangan intelektual, sosial, dan emosional siswa dan merupakan penunjang keberhasilan dalam mempelajari semua bidang studi. ${ }^{3}$ Pembelajaran bahasa diharapkan membantu siswa mengenal dirinya, budayanya, dan budaya orang lain,

\footnotetext{
${ }^{1}$ Slameto, Belajar dan Faktor-faktor yang Mempengaruhinya (Jakarta: Rineka Cipta,2013),hlm.57.

${ }^{2}$ Sudarsana, dkk, Pembinaan Minat Baca (Jakarta: Universitas Terbuka, 2010), hlm. 4,27.

${ }^{3}$ BSNP, Standar Isi untuk Satuan Pendidikan Dasar dan Menengah, (Jakarta: BSNP,2006), hlm.119.
} 
STAINU Purworejo: Jurnal As Sibyan

Jurnal Kajian Kritis Pendidikan Islam

Vol 4 No 1 Januari - Juni 2021

dan Manajemen Pendidikan Dasar

Homepage: https://ejournal.stainupwr.ac.id/

Email: sibyan.stainupwrj@gmail.com

E-ISSN: : 2599-2732

mengemukakan gagasan dan perasaan, berpartisipasi dalam masyarakat yang menggunakan bahasa tersebut, dan menemukan serta menggunakan kemampuan analitis dan imaginative yang ada dalam dirinya. Oleh karena itu, di SD seluruh Indonesia dilaksanakan pembelajaran Bahasa Indonesia. Ruang lingkup mata pelajaran Bahasa Indonesia di SD mencakup empat aspek ketrampilan berbahasa, yaitu mendengar/menyimak, berbicara, membaca dan menulis (BSNP, 2006: 120). ${ }^{4}$

Zaman era Globalisasi ini, banyak siswa yang tidak minat untuk membaca, mereka lebih suka bermain HP, katimbang belajar. Dari masalah itu, muncullah siswa yang tidak berprestasi karena tidak bisa menggunakan waktunya dengan sebaik mungkin. Prestasi mereka menurun, dan bahkan nilai-nilainyapun semakin jelek. Banyak dari kalangan anak kecil yang kurang minat dalam membaca, sehingga penulis tertarik untuk meneliti permasalahan tersebut, untuk meningkatkan prestasi belajar mereka, sehingga mereka lebih suka untuk belajar dan prestasinya naik.

Sehingga penulis merasa tertarik untuk melakukan penelitian lebih mendalam tentang: "Pengaruh Minat Membaca Siswa Terhadap Prestasi Belajar Bahasa

\section{Indonesia Siswa Kelas III MIN 3 Purworejo Tahun Ajaran 2019/2020”.}

Adapun hal yang ingin peneliti ketahui antara lain: bagaimana minat membaca, bagaimana prestasi belajar Bahasa Indonesia, bagaimana pengaruh antara minat membaca dengan prestasi belajar Bahasa Indonesia siswa kelas III MIN 3 Purworejo.

\section{B. METODOLOGI}

Penelitian yang dilakukan adalah penelitian kuantitatif dengan menggunakan teknik statistik inferensial, yaitu teknik statistik yang digunakan untuk menganalisis data sampel dan hasilnya berlaku untuk populasi. Pendekatan yang penulis gunakan untuk penelitian ini adalah Penelitian Lapangan (field research). Populasi

\footnotetext{
${ }^{4}$ Ibid.,hlm.120.
} 
STAINU Purworejo: Jurnal As Sibyan

Jurnal Kajian Kritis Pendidikan Islam

Vol 4 No 1 Januari - Juni 2021

dan Manajemen Pendidikan Dasar

Homepage: https://ejournal.stainupwr.ac.id/

Email: sibyan.stainupwrj@gmail.com

E-ISSN: : 2599-2732

Penelitian, yang digunakan adalah MIN 3 Purworejo. Sampel adalah sebagian dari jumlah dan karakteristik yang dimiliki oleh populasi tersebut, ataupun bagian kecil dari anggota populasi yang diambil menurut prosedur tertentu sehingga dapat mewakili populasinya. Sampel yang digunakan disini adalah siswa kelas III MIN 3 Purworejo, yang berjumlah 46 siswa, dengan meggunakan angket, Karena dengan menggunakan angket, akan mempermudah penulis dalam melakukan penelitian terhadap bakat minat membaca terhadap prestasi belajar Bahasa Indonesia siswa kelas III.

Teknik pengumpulan data penelitian dilakukan melalui tahapan-tahapan sebagai berikut:

1. Penyusunan instrument penelitian.

2. Pembagian instrumen kepada responden secara acak, untuk diisi sesuai dengan petunjuk yang telah disiapkan.

3. Penarikan instrument penelitian telah diisi oleh responden.

4. Tabulasi data hasil penelitian.

5. Analisis data hasil penelitian dengan rumus statistik.

Teknik Analisis Data yang penulis gunakan adalah dengan teknik statistik parametrik atau nonparametrik. Penulis Menggunakan Rumus Regresi Linear Sederhana dengan rumus:

1. Uji Normalitas dengan metode Kolmogrov-Smirnow

a. Menghitung Nilai $D_{\text {hitung }}$ :

Menentukan nilai kolom kedua $\left(\mathrm{K}_{2}\right)$

$\mathrm{K}_{2}=\frac{i-1}{n}$ dengan $\mathrm{I}=$ sampel ke... I dan $\mathrm{n}=$ jumlah data

b. Menentukan nilai kolom ketiga $\left(\mathrm{K}_{3}\right)$

$$
\mathrm{K}_{3}=\frac{i}{n}
$$

c. Menentukan nilai kolom keempat $\left(\mathrm{K}_{4}\right)$

Nilai kolom keempat diperoleh dengan cara mnegurutkan data ( $t i)$ dari yang terkecil sampai yang terbesar.

d. Menentukan nilai kolom kelima (probability) 


\section{dan Manajemen Pendidikan Dasar}

Homepage: https://ejournal.stainupwr.ac.id/

Email: sibyan.stainupwrj@gmail.com

E-ISSN: : 2599-2732

1) Membuat tabel penolong

2) Rata-rata pengukuran

$$
\mathrm{t}=\frac{\sum t_{1}}{n}
$$

3) Standar Deviasi

$$
\mathrm{s}=\sqrt{\frac{\sum\left(t_{i-t}\right)^{2}}{n-1}}
$$

4) Menghitung nilai Probability (p)

$$
p=\frac{t_{1}-t}{s}
$$

e. Menghitung nilai kolom keenam (cumulative probability)

f. Menentukan nilai kolom ketujuh $\left(\mathrm{D}_{1}\right)$

$$
\mathrm{D}_{1}=\max \left\{\varnothing\left(\frac{t_{1-t}}{s}\right)-\frac{i-1}{n}\right\}
$$

g. Menentukan nilai kolom kedelapan $\left(\mathrm{D}_{2}\right)$

$$
\mathrm{D}_{2}=\max \left\{\frac{i}{n}-\emptyset\left(\frac{t_{i-t}}{s}\right)\right\}
$$

h. Membuat tabel penolong

i. Menentukan nilai $D_{\text {tabel }}$

j. Membuat keputusan

2. Rumus Regresi Linear Sederhana

a. Rumus Regresi Linear Sederhana

$$
Y=a+b . X
$$

Keterangan:

$\mathrm{Y}=$ variabel terikat

$\mathrm{X}=$ variabel bebas

$$
\mathrm{a} \text { dan } \mathrm{b}=\text { konstanta }
$$

b. Mencari nilai Konstanta b:

$$
\mathrm{b}=\frac{n \cdot \sum X Y-\sum X \cdot \sum Y}{n \cdot \sum X^{2}-\left(\sum X^{2}\right)}
$$

c. Mencari nilai konstanta a

$$
\mathrm{a}=\frac{\sum Y-b \cdot \sum X}{n}
$$

Keterangan: 


$$
\mathrm{n}=\text { jumlah data }
$$

d. Membuat persamaan regresi

$$
\mathrm{Y}=\mathrm{a}+\mathrm{b} . \mathrm{X}
$$

3. Perhitungan Korelasi Sederhana Product Moment Pearson, yang dirumuskan sebagai berikut:

$$
\mathrm{r}_{\mathrm{xy}}=\frac{n \cdot\left(\sum X Y\right)-\left(\sum X\right)\left(\sum Y\right)}{\sqrt{\left[n \cdot\left(\sum X^{2}\right)-\left(\sum X\right)^{2}\right]\left[n \cdot\left(\sum Y^{2}\right)-\left(\sum Y\right)^{2}\right]}}
$$

4. Prosedur Uji Linieritas
a. Menentukan hipotesis
b. Membuat hipotesis dalam bentuk model statistik
c. Menentukan taraf signifikan $a$
d. Kaidah pengujian:

Jika: $F_{\text {hitung }} \leq \mathrm{F}_{\text {tabel }}$, maka $\mathrm{H}_{\mathrm{o}}$ diterima

Jika: $\mathrm{F}_{\text {hitung }}>\mathrm{F}_{\text {tabel }}$, maka $\mathrm{H}_{\mathrm{o}}$ ditolak

e. Menghitung Nilai $F_{\text {hitung }}$

1) Menghitung jumlah kuadrat regresi [ JK reg a (b/a) $]$

$$
\left(\mathrm{JK}_{\text {reg a }}\right)=\frac{\left(\sum Y\right)^{2}}{n}
$$

2) Menghitung jumlah kuadrat regresi $\left[\mathrm{JK}_{\text {reg a (b/a) }}\right]$

$$
\left[\mathrm{JK}_{\mathrm{reg} \text { a (b/a) }}\right]=\mathrm{b}\left[\sum X Y-\frac{\sum X \cdot \sum Y}{n}\right]
$$

3) Menghitung jumlah kuadrat residu [ $\left[\mathrm{JK}_{\mathrm{res}}\right]$

$$
\mathrm{JK}_{\text {res }}=\sum Y^{2}-\left\{\mathrm{JK}_{\text {reg a (b/a) }}+\mathrm{JK}_{\text {reg (a) }}\right\}
$$

4) Menghitung rata-rata jumlah kuadrat regresi [ RJK reg(a) ]

$$
\mathrm{RJK}_{\text {reg (a) }}=\mathrm{JK}_{\text {reg (a) }}
$$

5) Menghitung rata-rata jumlah kuadrat regresi $\left[\mathrm{RJK}_{\mathrm{reg}(\mathrm{b} / \mathrm{a})}\right]$

$$
\mathrm{RJK}_{\text {reg }(\mathrm{b} / \mathrm{a})}=\mathrm{JK}_{\text {reg }(\mathrm{b} / \mathrm{a})}
$$

6) Menghitung rata-rata jumlah kuadrat residu [RJK $\left.\mathrm{Res}_{\text {res }}\right]$

$$
\mathrm{RJK}_{\text {res }}=\frac{\mathrm{JKres}}{n-2}
$$

7) Membandingkan $F_{\text {hitung }}$ dan $\mathrm{F}_{\text {tabel }}$ 
STAINU Purworejo: Jurnal As Sibyan

Jurnal Kajian Kritis Pendidikan Islam

\section{dan Manajemen Pendidikan Dasar}

Homepage: https://ejournal.stainupwr.ac.id/

Email: sibyan.stainupwrj@gmail.com

E-ISSN: : 2599-2732

8) Membuat keputusan apakah $\mathrm{H}_{\mathrm{a}}$ atau $\mathrm{H}_{\mathrm{o}}$ yang diterima Menerima atau menolak $\mathrm{H}_{\mathrm{o}}$

5. Prosedur Uji Signifikansi

a. Membuat hipotesis dalam uraian kalimat

b. Membuat hipotesis dalam bentuk model statistik

c. Menentukan taraf signifikan $(a)$

d. Kaidah Pengujian

$\mathrm{Jika}-\mathrm{t}_{\text {tabel }} \leq \mathrm{t}_{\text {hitung }} \leq \mathrm{t}_{\text {tabel }}$, maka $\mathrm{H}_{\mathrm{o}}$ diterima

Jika $\mathrm{t}_{\text {hitung }}>\mathrm{t}_{\text {tabel }}$, maka $\mathrm{H}_{\mathrm{o}}$ ditolak

e. Menghitung $t_{\text {hitung }}$ dan $t_{\text {tabel }}$

$$
\begin{aligned}
& \mathrm{t}_{\text {hitung }}=\frac{r \sqrt{n}-2}{\sqrt{1}-(r)^{2}} \\
& \mathrm{t}_{\text {tabel }}=\mathrm{t}_{(\mathrm{a} / 2)(\mathrm{n}-2)}
\end{aligned}
$$

Nilai $\mathrm{t}_{\text {tabel }}$ dapat dicari dengan menggunakan tabel $t$-Student .

Bila pengujian dua sisi, maka nilai $a$ dibagi 2 .

f. Membandingkan $\mathrm{t}_{\text {tabel }}$ dan $\mathrm{t}_{\text {hitung }}$

g. Mengambil keputusan

h. Menerima atau menolak $\mathrm{H}_{0}{ }^{5}$

\section{HASIL DAN PEMBAHASAN}

\section{Analisis Deskriptif}

\section{a. Minat Membaca Siswa}

Berikut adalah hasil data tentang minat baca Siswa kelas III di MIN 3

Purworejo, terdapat pada tabel dibawah ini:

Tabel 14

Hasil Minat Membaca Siswa

\begin{tabular}{|l|l|l|l|l|l|}
\hline No. & Nama & Skor & No. & Nama & Skor \\
\hline 1 & Adib Fathurrozi & 47 & 24 & Afifah Azzahra & 54 \\
\hline 2 & Afif Muzaqi & 45 & 25 & Afrina Putri & 42 \\
\hline 3 & Afiqoh D.N & 47 & 26 & Aliya Mulyawanti & 43 \\
\hline
\end{tabular}

${ }^{5}$ Siregar, Syofian, Statistik Parametrik untuk Penelitian Kuantitatif, (Jakarta: Bumi Aksara, 2017), hlm. 379-383. 
STAINU Purworejo: Jurnal As Sibyan Jurnal Kajian Kritis Pendidikan Islam

\section{dan Manajemen Pendidikan Dasar}

Homepage: https://ejournal.stainupwr.ac.id/

Email: sibyan.stainupwrj@gmail.com

E-ISSN: : 2599-2732

\begin{tabular}{|c|c|c|c|c|c|}
\hline 4 & Aqil M.A & 46 & 27 & Almira Rahma Digna & 53 \\
\hline 5 & Aldiyano. F & 37 & 28 & Alya Nurmaila Wening & 52 \\
\hline 6 & Alfadhila N.N & 46 & 29 & Ananda Putra Pratama & 44 \\
\hline 7 & Andi Rizki I. & 44 & 30 & Azka Ghulam Aprilian & 49 \\
\hline 8 & Daffa M.A & 50 & 31 & Bayu Aji Pamungkas & 44 \\
\hline 9 & Fitri Paula & 44 & 32 & Dias Ardiyansyah & 46 \\
\hline 10 & Haydar F. & 54 & 33 & Elsa Dinara & 50 \\
\hline 11 & Khafid Rifky A. & 43 & 34 & Ferdiansyah Maulana & 54 \\
\hline 12 & Malika Zahra I. & 41 & 35 & Irfan Epri Nugroho & 43 \\
\hline 13 & M. Ikhsan Kamil & 42 & 36 & $\begin{array}{l}\text { Muhammad } \\
\text { Amrulloh }\end{array}$ & 38 \\
\hline 14 & M. Zuhruf Anam & 46 & 37 & Muhammad Faisal & 45 \\
\hline 15 & Nafla Hafiza & 54 & 38 & Muhammad Fatih & 43 \\
\hline 16 & Najma Husni J. & 51 & 39 & $\begin{array}{l}\text { Muhammad Naufal } \\
\text { Adhitya }\end{array}$ & 43 \\
\hline 17 & Novia Nilnal M. & 51 & 40 & Muhammad Nur Fahmi & 38 \\
\hline 18 & Rakha Z.N & 49 & 41 & $\begin{array}{ll}\text { Muhammad } & \text { Rizky } \\
\text { Destian }\end{array}$ & 43 \\
\hline 19 & Ramya A.D & 54 & 42 & Nur'aini Mushdzalifa & 49 \\
\hline 20 & Rangga W.K & 49 & 43 & Qafa Fadilla Ardiansyah & 44 \\
\hline 21 & Tiara Naswa K. & 49 & 44 & Rafa Arsyad Mubarok & 46 \\
\hline 22 & Wilda Nur A. & 46 & 45 & Raihan Setyawan & 41 \\
\hline 23 & Adil Darmawan & 48 & 46 & Taufiq Qurrahman & 47 \\
\hline
\end{tabular}

\begin{tabular}{lrr} 
& & Statistics \\
Var0001 & \\
$N$ & Valid & 46 \\
\cline { 2 - 3 } & Missing & 0 \\
\hline Mean & & 46.39 \\
\hline Median & 46.00 \\
\hline Mode & $43^{\mathrm{a}}$ \\
\hline Range & 17 \\
\hline Minimum & 37 \\
\hline Maximum & 54 \\
\hline Sum & 2134 \\
\hline
\end{tabular}

a. Multiple modes exist. The smallest value is shown

\section{b. Pembelajaran Bahasa Indonesia}

Berikut adalah hasil dari pengisisian angket pada variabel dependen, dapat dilihat pada tabel di bawah ini:

Tabel 15

Skor Hasil Angket Pembelajaran Bahasa Indonesia 
STAINU Purworejo: Jurnal As Sibyan Jurnal Kajian Kritis Pendidikan Islam

\section{dan Manajemen Pendidikan Dasar}

Homepage: https://ejournal.stainupwr.ac.id/

Email: sibyan.stainupwrj@gmail.com

E-ISSN: : 2599-2732

\begin{tabular}{|c|l|l|r|l|l|}
\hline No. & Nama & Skor & No. & Nama & Skor \\
\hline 1 & Adib Fathurrozi & 15 & 23 & Adil Darmawan & 16 \\
\hline 2 & Afif Muzaqi & 15 & 24 & Afifah Azzahra & 18 \\
\hline 3 & Afiqoh D.N & 14 & 25 & Afrina Putri & 14 \\
\hline 4 & Aqil M.A & 15 & 26 & Aliya Mulyawanti & 13 \\
\hline 5 & Aldiyano. F & 12 & 27 & Almira Rahma Digna & 18 \\
\hline 6 & Alfadhila N.N & 16 & 28 & Alya Nurmaila Wening & 18 \\
\hline 7 & Andi Rizki I. & 12 & 29 & Ananda Putra Pratama & 16 \\
\hline 8 & Daffa M.A & 17 & 30 & Azka Ghulam Aprilian & 18 \\
\hline 9 & Fitri Paula & 16 & 31 & Bayu Aji Pamungkas & 14 \\
\hline 10 & Haydar F. & 18 & 32 & Dias Ardiyansyah & 14 \\
\hline 11 & Khafid Rifky A. & 16 & 33 & Elsa Dinara & 16 \\
\hline 12 & Malika Zahra I. & 15 & 34 & Ferdiansyah Maulana & 18 \\
\hline 13 & M. Ikhsan Kamil & 13 & 35 & Irfan Epri Nugroho & 15 \\
\hline 14 & M. Zuhruf Anam & 16 & 36 & Muhammad & 13 \\
\hline 15 & Nafla Hafiza & 18 & 37 & Muhammad Faisal & 14 \\
\hline 16 & Najma Husni J. & 17 & 38 & Muhammad Fatih & 15 \\
\hline 17 & Novia Nilnal M. & 18 & 39 & $\begin{array}{c}\text { Muhammad } \\
\text { Adhitya }\end{array}$ & 15 \\
\hline 18 & Rakha Z.N & 17 & 40 & Muhammad Nur Fahmi & 12 \\
\hline 19 & Ramya A.D & 18 & 41 & Muhammad Rizky Destian & 14 \\
\hline 20 & Rangga W.K & 17 & 42 & Nur'aini Mushdzalifa & 14 \\
\hline 21 & Tiara Naswa K. & 17 & 43 & Qafa Fadilla Ardiansyah & 14 \\
\hline 22 & Wilda Nur A. & Rafa Arsyad Mubarok & 14 \\
\hline
\end{tabular}

\begin{tabular}{llr} 
& & Statistics \\
Var0002 & \\
& Valid & 46 \\
\cline { 2 - 3 } & Missing & 0 \\
\hline Mean & & 15.5217 \\
\hline Median & 15.5000 \\
\hline Mode & $14.00^{\mathrm{a}}$ \\
\hline Range & 6.00 \\
\hline Minimum & 12.00 \\
\hline Maximum & 18.00 \\
\hline Sum & 714.00 \\
\hline
\end{tabular}

\section{c. Prestasi Bahasa Indonesia (Praktek membaca)}


STAINU Purworejo: Jurnal As Sibyan

Jurnal Kajian Kritis Pendidikan Islam

dan Manajemen Pendidikan Dasar

Homepage: https://ejournal.stainupwr.ac.id/

Email: sibyan.stainupwrj@gmail.com

E-ISSN: : 2599-2732

Berikut adalah nilai praktek membaca siswa kelas III, dapat dilihat pada tabel berikut:

Tabel 16

Hasil Nilai Praktek Membaca

\begin{tabular}{|c|c|c|c|c|c|}
\hline No. & Nama & Skor & No. & Nama & Skor \\
\hline 1 & Adib Fathurrozi & 88 & 24 & Afifah Azzahra & 75 \\
\hline 2 & Afif Muzaqi & 89 & 25 & Afrina Putri & 85 \\
\hline 3 & Afiqoh D.N & 86 & 26 & Aliya Mulyawanti & 80 \\
\hline 4 & Aqil M.A & 85 & 27 & Almira Rahma Digna & 75 \\
\hline 5 & Aldiyano. F & 80 & 28 & $\begin{array}{cc}\text { Alya } & \text { Nurmaila } \\
\text { Wening } & \end{array}$ & 80 \\
\hline 6 & Alfadhila N.N & 87 & 29 & Ananda Putra Pratama & 70 \\
\hline 7 & Andi Rizki I. & 88 & 30 & Azka Ghulam Aprilian & 80 \\
\hline 8 & Daffa M.A & 88 & 31 & Bayu Aji Pamungkas & 75 \\
\hline 9 & Fitri Paula & 80 & 32 & Dias Ardiyansyah & 80 \\
\hline 10 & Haydar F. & 88 & 33 & Elsa Dinara & 75 \\
\hline 11 & Khafid Rifky A. & 87 & 34 & Ferdiansyah Maulana & 80 \\
\hline 12 & Malika Zahra I. & 80 & 35 & Irfan Epri Nugroho & 80 \\
\hline 13 & M. Ikhsan Kamil & 90 & 36 & $\begin{array}{l}\text { Muhammad Adib } \\
\text { Amrulloh }\end{array}$ & 80 \\
\hline 14 & M. Zuhruf Anam & 88 & 37 & Muhammad Faisal & 75 \\
\hline 15 & Nafla Hafiza & 88 & 38 & Muhammad Fatih & 80 \\
\hline 16 & Najma Husni J. & 88 & 39 & $\begin{array}{l}\text { Muhammad Naufal } \\
\text { Adhitya }\end{array}$ & 75 \\
\hline 17 & Novia Nilnal M. & 83 & 40 & $\begin{array}{l}\text { Muhammad Nur } \\
\text { Fahmi }\end{array}$ & 75 \\
\hline 18 & Rakha Z.N & 90 & 41 & $\begin{array}{l}\text { Muhammad Rizky } \\
\text { Destian }\end{array}$ & 75 \\
\hline 19 & Ramya A.D & 89 & 42 & Nur'aini Mushdzalifa & 80 \\
\hline 20 & Rangga W.K & 86 & 43 & $\begin{array}{ll}\text { Qafa } & \text { Fadilla } \\
\text { Ardiansyah } & \\
\end{array}$ & 75 \\
\hline 21 & Tiara Naswa K. & 85 & 44 & Rafa Arsyad Mubarok & 85 \\
\hline 22 & Wilda Nur A. & 86 & 45 & Raihan Setyawan & 75 \\
\hline 23 & Adil Darmawan & 86 & 46 & Taufiq Qurrahman & 75 \\
\hline
\end{tabular}




\begin{tabular}{llr} 
& \multicolumn{2}{c}{ Statistics } \\
Var0003 & & \\
$N$ & Valid & 46 \\
\cline { 2 - 3 } & Missing & 0 \\
\hline Mean & & 81.96 \\
\hline Median & 80.00 \\
\hline Mode & 80 \\
\hline Range & 20 \\
\hline Minimum & 70 \\
\hline Maximum & 90 \\
\hline Sum & 3770 \\
\hline
\end{tabular}

\section{Uji Hipotesis}

Salah satu alat yang dapat digunakan dalam memprediksi permintaan di masa yang akan datang dengan berdasarkan data masa lalu, atau untuk mengetahui pengaruh satu variabel bebas (independent) terhadap satu variabel tak bebas (dependent) adalah menggunakan regresi linear. Regresi linear dibagi ke dalam dua kategori, yaitu regresi linear sederhana dan regresi linear berganda. Regresi linear sederhana digunakan hanya untuk satu variabel bebas (independent) dan satu variabel tak bebas (dependent). Sedangkan regresi linear berganda digunakan untuk satu variabel tak bebas (dependent) dan dua atau lebih variabel bebas (independent). Tujuan penerapan kedua metode ini adalah untuk meramalkan atau memprediksi besaran nilai variabel tak bebas (dependent) yang dipengaruhi oleh variabel bebas (independent).

Rumus Regresi Linear Sederhana sebagai berikut:

$\mathrm{Y}=\mathrm{a}+\mathrm{b} \cdot \mathrm{X}$

Keterangan:

$\mathrm{Y}=$ variabel terikat

$\mathrm{X}=$ variabel bebas 
STAINU Purworejo: Jurnal As Sibyan

Jurnal Kajian Kritis Pendidikan Islam

dan Manajemen Pendidikan Dasar

Homepage: https://ejournal.stainupwr.ac.id/

Email: sibyan.stainupwrj@gmail.com

E-ISSN: : 2599-2732

$\mathrm{a}$ dan $\mathrm{b}=$ konstanta $^{6}$

Sebelum membuat rumus regresi linear sederhana, penulis harus menentukan nilai konstanta $a$ dan nilai konstanta $b$, dengan bantuan tabel penolong sebagai berikut:

Tabel 17

Tabel Penolong, Hasil Variabel X dan Y

\begin{tabular}{|c|c|c|c|c|c|}
\hline No. & $X$ & $\mathrm{Y}$ & X.Y & $X^{2}$ & $\mathrm{Y}^{2}$ \\
\hline 1 & 47 & 15 & 705 & 2209 & 225 \\
\hline 2 & 45 & 15 & 675 & 2025 & 225 \\
\hline 3 & 47 & 14 & 658 & 2209 & 196 \\
\hline 4 & 46 & 15 & 690 & 2116 & 225 \\
\hline 5 & 37 & 12 & 444 & 1369 & 144 \\
\hline 6 & 46 & 16 & 736 & 2116 & 256 \\
\hline 7 & 44 & 12 & 528 & 1936 & 144 \\
\hline 8 & 50 & 17 & 850 & 2500 & 289 \\
\hline 9 & 44 & 16 & 704 & 1936 & 256 \\
\hline 10 & 54 & 18 & 972 & 2916 & 324 \\
\hline 11 & 43 & 16 & 688 & 1849 & 256 \\
\hline 12 & 41 & 15 & 615 & 1681 & 225 \\
\hline 13 & 42 & 13 & 546 & 1764 & 169 \\
\hline 14 & 46 & 16 & 736 & 2116 & 256 \\
\hline 15 & 54 & 18 & 972 & 2916 & 324 \\
\hline 16 & 51 & 17 & 867 & 2601 & 289 \\
\hline 17 & 51 & 18 & 918 & 2601 & 324 \\
\hline 18 & 49 & 17 & 833 & 2401 & 289 \\
\hline 19 & 54 & 18 & 972 & 2916 & 324 \\
\hline 20 & 49 & 17 & 833 & 2401 & 289 \\
\hline 21 & 49 & 17 & 833 & 2401 & 289 \\
\hline 22 & 46 & 17 & 782 & 2116 & 289 \\
\hline 23 & 48 & 16 & 768 & 2304 & 256 \\
\hline 24 & 54 & 18 & 972 & 2916 & 324 \\
\hline 25 & 42 & 14 & 588 & 1764 & 196 \\
\hline 26 & 43 & 13 & 559 & 1849 & 169 \\
\hline 27 & 53 & 18 & 954 & 2809 & 324 \\
\hline 28 & 52 & 18 & 936 & 2704 & 324 \\
\hline 29 & 44 & 16 & 704 & 1936 & 256 \\
\hline 30 & 49 & 18 & 882 & 2401 & 324 \\
\hline 31 & 44 & 14 & 616 & 1936 & 196 \\
\hline
\end{tabular}

${ }^{6}$ Siregar Syofian, Statistik Parametrik untuk Penelitian Kuantitatif, (Jakarta: Bumi Aksara, 2017), hlm. 379. 
STAINU Purworejo: Jurnal As Sibyan Jurnal Kajian Kritis Pendidikan Islam

\section{dan Manajemen Pendidikan Dasar}

Homepage: https://ejournal.stainupwr.ac.id/

Email: sibyan.stainupwrj@gmail.com

E-ISSN: : 2599-2732

\begin{tabular}{|c|c|c|c|c|c|}
32 & 46 & 14 & 644 & 2116 & 196 \\
\hline 33 & 50 & 16 & 800 & 2500 & 256 \\
\hline 34 & 54 & 18 & 972 & 2916 & 324 \\
\hline 35 & 43 & 15 & 645 & 1849 & 225 \\
\hline 36 & 38 & 13 & 494 & 1444 & 169 \\
\hline 37 & 45 & 14 & 630 & 2025 & 196 \\
\hline 38 & 43 & 15 & 645 & 1849 & 225 \\
\hline 39 & 43 & 15 & 645 & 1849 & 225 \\
\hline 40 & 38 & 12 & 456 & 1444 & 144 \\
\hline 41 & 43 & 14 & 602 & 1849 & 196 \\
\hline 42 & 49 & 14 & 686 & 2401 & 196 \\
\hline 43 & 44 & 14 & 616 & 1936 & 196 \\
\hline 44 & 46 & 14 & 644 & 2116 & 196 \\
\hline 45 & 41 & 15 & 615 & 1681 & 225 \\
\hline 46 & 47 & 17 & 799 & 2209 & 289 \\
\hline & $\sum X=$ & $\sum Y=$ & $\sum X Y=$ & $\sum X^{2}=$ & $\sum Y^{2}=$ \\
Jumah & 2134 & 714 & 33429 & 99898 & 11234 \\
\hline
\end{tabular}

a. Uji Normalitas dengan dengan metode Kolmogorov-Smirnow

Uji Normalitas Kolmogorov Smirnow merupakan bagian dari uji asumsi klasik. Uji Normalitas bertujuan untuk mengetahui apakah nilai residual berdistribusi normal atau tidak. Model regresi yang baik adalah memiliki nilai residual yang berdistribusi normal.

Berikut ini adalah penghitungan Uji Normalitas menggunakan metode Kolmogorov-Smirnow dengan aplikasi SPSS:

Tabel 18

Hasil Residu Variabel X dan Y

\begin{tabular}{|c|c|c|c|c|c|c|c|}
\hline $\begin{array}{c}\text { Resp } \\
\text { onden }\end{array}$ & $\begin{array}{c}\text { Variabel } \\
\text { X }\end{array}$ & $\begin{array}{c}\text { Variabel } \\
\text { Y }\end{array}$ & $\begin{array}{c}\text { Nilai } \\
\text { RES_1 }\end{array}$ & $\begin{array}{c}\text { Resp } \\
\text { onden }\end{array}$ & $\begin{array}{c}\text { Variabel } \\
\text { X }\end{array}$ & $\begin{array}{c}\text { Variabel } \\
\text { Y }\end{array}$ & $\begin{array}{c}\text { Nilai } \\
\text { RES_1 }\end{array}$ \\
\hline 1 & 47 & 15 & -0.72867 & 24 & 54 & 18 & -0.10839 \\
\hline 2 & 45 & 15 & -0.04875 & 25 & 42 & 14 & -0.02887 \\
\hline 3 & 47 & 14 & -1.72867 & 26 & 43 & 13 & -1.36883 \\
\hline 4 & 46 & 15 & -0.38871 & 27 & 53 & 18 & 0.23157 \\
\hline 5 & 37 & 12 & -0.32908 & 28 & 52 & 18 & 0.57153 \\
\hline 6 & 46 & 16 & 0.61129 & 29 & 44 & 16 & 1.29121 \\
\hline 7 & 44 & 12 & -2.70879 & 30 & 49 & 18 & 1.59141 \\
\hline
\end{tabular}


STAINU Purworejo: Jurnal As Sibyan Jurnal Kajian Kritis Pendidikan Islam

\section{dan Manajemen Pendidikan Dasar}

Homepage: https://ejournal.stainupwr.ac.id/

Email: sibyan.stainupwrj@gmail.com

E-ISSN: : 2599-2732

\begin{tabular}{|c|c|c|c|c|c|c|c|}
\hline 8 & 50 & 17 & 0.25145 & 31 & 44 & 14 & -0.70879 \\
\hline 9 & 44 & 16 & 1.29121 & 32 & 46 & 14 & -1.38871 \\
\hline 10 & 54 & 18 & -0.10839 & 33 & 50 & 16 & -0.74855 \\
\hline 11 & 43 & 16 & 1.63117 & 34 & 54 & 18 & -0.10839 \\
\hline 12 & 41 & 15 & 1.31109 & 35 & 43 & 15 & 0.63117 \\
\hline 13 & 42 & 13 & -1.02887 & 36 & 38 & 13 & 0.33096 \\
\hline 14 & 46 & 16 & 0.61129 & 37 & 45 & 14 & -1.04875 \\
\hline 15 & 54 & 18 & -0.10839 & 38 & 43 & 15 & 0.63117 \\
\hline 16 & 51 & 17 & -0.08851 & 39 & 43 & 15 & 0.63117 \\
\hline 17 & 51 & 18 & 0.91149 & 40 & 38 & 12 & -0.66904 \\
\hline 18 & 49 & 17 & 0.59141 & 41 & 43 & 14 & -0.36883 \\
\hline 19 & 54 & 18 & -0.10839 & 42 & 49 & 14 & -2.40859 \\
\hline 20 & 49 & 17 & 0.59141 & 43 & 44 & 14 & -0.70879 \\
\hline 21 & 49 & 17 & 0.59141 & 44 & 46 & 14 & -1.38871 \\
\hline 22 & 46 & 17 & 1.61129 & 45 & 41 & 15 & 1.31109 \\
\hline 23 & 48 & 16 & -0.06863 & 46 & 47 & 17 & 1.27133 \\
\hline
\end{tabular}

One-Sample Kolmogorov-Smirnov Test

\begin{tabular}{|c|c|c|}
\hline & & $\begin{array}{l}\text { Unstandardized } \\
\text { Residual }\end{array}$ \\
\hline $\mathrm{N}$ & & 46 \\
\hline \multirow[t]{2}{*}{ Normal Parameters ${ }^{a, b}$} & Mean & .0000000 \\
\hline & Std. Deviation & 1.02830735 \\
\hline \multirow[t]{3}{*}{ Most Extreme Differences } & Absolute & .110 \\
\hline & Positive & .074 \\
\hline & Negative & -.110 \\
\hline \multicolumn{2}{|l|}{ Test Statistic } & .110 \\
\hline \multicolumn{2}{|l|}{ Asymp. Sig. (2-tailed) } & $200^{c, d}$ \\
\hline \multicolumn{3}{|c|}{$\begin{array}{l}\text { a. Test distribution is Normal. } \\
\text { b. Calculated from data. } \\
\text { c. Lilliefors Sianificance Correct }\end{array}$} \\
\hline
\end{tabular}

Berdasarkan hasil Uji Normalitas diketahui nilai Signifikansi 0,200, penulis menggunkan taraf signifikansi 0,05, dengan jumlah responden 46. Maka dapat dilihat pada tabel Nilai Kritiss Uji Kolmgrov-Smirnov.

Tabel 19

Nilai Kritis Uji Kolmogorov-Smirnow 


\section{dan Manajemen Pendidikan Dasar}

Homepage: https://ejournal.stainupwr.ac.id/

Email: sibyan.stainupwrj@gmail.com

E-ISSN: : 2599-2732

Tabel Nilai Kritis Uji Kolmogorov-Smirnov

$\begin{array}{rrrrrr}\mathbf{n} & \boldsymbol{\alpha}=\mathbf{0 , 2 0} & \boldsymbol{\alpha}=\mathbf{0 , 1 0} & \boldsymbol{\alpha}=\mathbf{0 , 0 5} & \boldsymbol{\alpha}=\mathbf{0 , 0 2} & \boldsymbol{\alpha}=\mathbf{0 , 0 1} \\ 26 & 0,204 & 0,233 & 0,259 & 0,290 & 0,311 \\ 27 & 0,200 & 0,229 & 0,254 & 0,284 & 0,305 \\ 28 & 0,197 & 0,225 & 0,250 & 0,279 & 0,300 \\ 29 & 0,193 & 0,221 & 0,246 & 0,275 & 0,295 \\ 30 & 0,190 & 0,218 & 0,242 & 0,270 & 0,290 \\ 35 & 0,177 & 0,202 & 0,224 & 0,251 & 0,269 \\ 40 & 0,165 & 0,189 & 0,210 & 0,235 & 0,252 \\ 45 & 0,156 & 0,179 & 0,198 & 0,222 & 0,238 \\ 50 & 0,148 & 0,170 & 0,188 & 0,211 & 0,226 \\ 55 & 0,142 & 0,162 & 0,180 & 0,201 & 0,216 \\ 60 & 0,136 & 0,155 & 0,172 & 0,193 & 0,207 \\ 65 & 0,131 & 0,149 & 0,166 & 0,185 & 0,199 \\ 70 & 0,126 & 0,144 & 0,160 & 0,179 & 0,192 \\ 75 & 0,122 & 0,139 & 0,154 & 0,173 & 0,185 \\ 80 & 0,118 & 0,135 & 0,150 & 0,167 & 0,179 \\ 85 & 0,114 & 0,131 & 0,145 & 0,162 & 0,174 \\ 90 & 0,111 & 0,127 & 0,141 & 0,158 & 0,169 \\ 95 & 0,108 & 0,124 & 0,137 & 0,154 & 0,165 \\ 100 & 0,106 & 0,121 & 0,134 & 0,150 & 0,161\end{array}$

Dari tabel diatas, dapat dilihat pada taraf signifikansi $a=0,05$ dengan jumlah rumus n-1, maka 46-1 = 45. Maka nilai kritisnya adalah 0,198. Maka dapat disimpulkan bahwa Nilai Signifikan pada uji Normalitas 0,200 > 0,198. Maka, nilai residual berdistribusi normal.

b. Rumus Regresi Linear Sederhana

Dari hasil data diatas, maka dapat dicari konstanta $b$ dengan menggunakan rumus sebagai berikut:

$$
\begin{aligned}
& b=\frac{\mathrm{n} \cdot \sum \mathrm{X} \cdot \mathrm{Y}-\sum \mathrm{X} \cdot \sum \mathrm{Y}}{\mathrm{n} \cdot \sum X^{2}-\left(\sum X\right)^{2}} \\
& =\frac{46.33429-2134.714}{46.99898-(2134) \cdot(2134)} \\
& =\frac{1537734-1523676}{4595308-4553956} \\
& =\frac{14058}{41352} \\
& =0,33
\end{aligned}
$$

Dari hasil perhitungan diatas, maka dapat diambil hasil bahwa nilai konstanta $b$ adalah 0,33 . Setelah penulis mendapatkan hasil dari konstanta $b$ maka langkah selanjutnya adalah menentukan nilai konstanta $a$ dengan menggunakan rumus sebagai berikut:

$$
a=\frac{\sum Y-b \cdot \sum X}{n}
$$


STAINU Purworejo: Jurnal As Sibyan Jurnal Kajian Kritis Pendidikan Islam

\section{dan Manajemen Pendidikan Dasar}

Homepage: https://ejournal.stainupwr.ac.id/

Email: sibyan.stainupwrj@gmail.com

E-ISSN: : 2599-2732

$$
\begin{aligned}
& =\frac{714-0,33 \cdot 2134}{46} \\
= & \frac{714-704,22}{46} \\
& =\frac{9,78}{46} \\
= & 0,21
\end{aligned}
$$

Dari hasil perhitungan diatas, maka dapat diambil hasil bahwa nilai konstanta a adalah 0,21 . Setelah penulis mendapatkan hasil dari nilai konstanta $a$, maka lagkah selanjutnya adalah membuat persamaan regresi dengan rumus sebagai berikut:

$$
\mathrm{Y}=a+b . \mathrm{X}
$$

Sehingga persamaan regresinya menjadi: $\mathbf{Y}=\mathbf{0 , 2 1}+\mathbf{0 , 3 3 X}$

\section{c. Rumus Korelasi Product Moment}

Perhitungan Korelasi Sederhana Product Moment Pearson, yang dirumuskan sebagai berikut:

$$
\begin{aligned}
r_{x y} & =\frac{n \cdot\left(\sum X Y\right)-\left(\sum X\right)\left(\sum Y\right)}{\sqrt{\left[n \cdot\left(\sum X^{2}\right)-\left(\sum X\right)^{2}\right]\left[n \cdot\left(\sum Y^{2}\right)-\left(\sum Y\right)^{2}\right]}} \\
& =\frac{46 \cdot(33429)-(2134)(714)}{\sqrt{\left(46(99898)-(2134)^{2}\right)\left(46(11234)-(714)^{2}\right.}} \\
& =\frac{46 \cdot(33429)-(2134)(714)}{\sqrt{\left.46(99898)-(2134)^{2}\right)\left(46(11234)-(714)^{2}\right.}} \\
& =\frac{1537734-1523676}{\sqrt{(4595308)-(4553956)(516764-509796)}} \\
& =\frac{14058}{\sqrt{(41352)}(6968)} \\
& =\frac{14058}{\sqrt{288140736}} \\
& =\frac{14058}{16974,70} \\
& =0,828 \\
r_{x y} & =0,828 \\
r_{x y} 2 & =0,828^{2} \\
& =0,685
\end{aligned}
$$

Dari perhitungan rumus diatas, maka dapat diambil kesimpulan bahwa:

$$
\mathbf{r}_{\text {hitung }}=0,828>\mathbf{r}_{\text {tabel }}=0,297 \text { dengan taraf signifikansi } 5 \% \text {. }
$$


STAINU Purworejo: Jurnal As Sibyan

Jurnal Kajian Kritis Pendidikan Islam

Vol 4 No 1 Januari - Juni 2021

dan Manajemen Pendidikan Dasar

Homepage: https://ejournal.stainupwr.ac.id/

Email: sibyan.stainupwrj@gmail.com

E-ISSN: : 2599-2732

Dapat dilihat pada tabel $r$ product moment pada tabel dibawah ini:

Tabel 20

Tabel $r$ Product Moment

\begin{tabular}{|c|c|c|c|c|c|}
\hline \multirow{2}{*}{4} & \multicolumn{2}{|c|}{ Taraf signifikanai } & \multirow{2}{*}{$\mathbf{A}$} & \multicolumn{2}{|c|}{ Tarat sipnifikanai } \\
\hline & $5 x$ & $+7 x$ & & $5 x$ & 14 \\
\hline $\begin{array}{l}3 \\
5\end{array}$ & 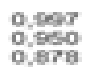 & $\begin{array}{l}\text { goge } \\
\text { goge }\end{array}$ & $\begin{array}{l}30 \\
+5\end{array}$ & $\begin{array}{l}0.900 \\
0395 \\
0312\end{array}$ & $\begin{array}{l}g=13 \\
g \neq 0\end{array}$ \\
\hline 6 & D.fint & ogt? & $=1$ & 0 300 & orset \\
\hline 7 & 0.75 & 6074 & $=2$ & $030=$ & 8500 \\
\hline B & dinor & Dasu & 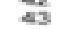 & 0301 & o, 36 \\
\hline 9 & deses & $67 a$ & 44 & $020 \%$ & 8364 \\
\hline no & 0,632 & ares & $\div 5$ & 6204 & 0,360 \\
\hline \pm 1 & 0,4000 & aras & $\infty$ & 0201 & 0.370 \\
\hline 12 & 0,576 & 070 & 47 & 028 & 0.312 \\
\hline 15 & 0.59 & Deb4 & $\Rightarrow$ & 0304 & 0,35 \\
\hline 18 & 0.52 & 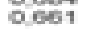 & 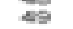 & opat & 0,304 \\
\hline 15 & 0,514 & $00-1$ & 50 & 0 279 & bist \\
\hline 19 & 0,497 & 9023 & 5 & 0200 & 0.545 \\
\hline 是 & disas & 0600 & 65 & 024 & 0317 \\
\hline 10 & $04 \pm 0$ & $65 \pi 5$ & $\pi$ & 0535 & 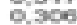 \\
\hline 20 & 0,44 & 0561 & $\pi 5$ & $052 \pi$ & 820 \\
\hline 21 & 0,499 & $0.5-0$ & $\infty$ & 0.200 & O.25et \\
\hline & Disar & D. 537 & as & 0213 & ozna \\
\hline 23 & 0.413 & 050 & $\infty$ & 0202 & 0270 \\
\hline 24 & 0,404 & osts & as & 0202 & 6203 \\
\hline 25 & 0,350 & Detas & 100 & 0.105 & 6200 \\
\hline 26 & 0. 330 & 0.40 & 125 & o.17s & 0.230 \\
\hline & $0, n=1$ & $0+42$ & 150 & 0.150 & 0.210 \\
\hline 20 & 0,374 & Duss & ins & 0.48 & 0,724 \\
\hline 29 & 0,307 & ouno & 200 & goas & 0,15 \\
\hline 30 & $0,3=1$ & 6463 & 300 & 0.113 & 6,14 \\
\hline 91 & 0.35s & 9450 & 40 & goge & $0.17 \mathrm{a}$ \\
\hline as & 0,49 & 0440 & 50 & goas & \\
\hline 35 & 034 & 0442 & 605 & 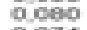 & otios \\
\hline 34 & 0.390 & 945 & 700 & $0 \mathrm{gr}$ & 6007 \\
\hline as & 0,304 & 0.430 & ect & a oro & bios: \\
\hline 36 & 0.300 & 0.424 & 000 & aows & Guater \\
\hline $3 T$ & 0.305 & $6+16$ & 1000 & bote? & bost \\
\hline
\end{tabular}

d. Uji Linieritas dan Uji Signifikan

Berikut ini penghitungan data dengan aplikasi SPSS untuk Uji Linieritas dan Uji Signifikansi, dapat dilihat pada tabel di bawah ini:

Descriptive Statistics

\begin{tabular}{lr|r|r} 
& Mean & Std. Deviation & \multicolumn{1}{c}{$\mathrm{N}$} \\
\hline Pembelajaran Bahasa Indonesia & 15.52 & 1.835 & 46 \\
\hline Minat Membaca Siswa & 46.39 & 4.470 & 46 \\
\hline
\end{tabular}

Dari tabel descriptive di atas, dapat dianalisis sebagai berikut:

1. Jumlah responden yang menjadi sampel sebanyak 46 siswa.

2. Rata-rata pembelajaran bahasa Indonesia adalah 15,52 dengan standar deviasi sebesar 1,835. Artinya jika dihubungkan dengan rata-rata pembelajaran Bahasa Indonesia dengan rata-rata 15, 52/ siswa, maka pembelajaran bahasa Indonesia akan berkisar antara 15, $52 \pm 1,835$. 
STAINU Purworejo: Jurnal As Sibyan Jurnal Kajian Kritis Pendidikan Islam

\begin{tabular}{|c|c|c|c|}
\hline \multicolumn{4}{|c|}{ Correlations } \\
\hline & & $\begin{array}{l}\text { Pembelajaran Bahasa } \\
\text { Indonesia }\end{array}$ & $\begin{array}{c}\text { Minat } \\
\text { Membaca Siswa }\end{array}$ \\
\hline \multirow{2}{*}{$\begin{array}{l}\text { Pearson } \\
\text { Correlation }\end{array}$} & Pembelajaran Bahasa Indonesia & 1.000 & .828 \\
\hline & Minat Membaca Siswa & .828 & 1.000 \\
\hline \multirow{2}{*}{$\begin{array}{l}\text { Sig. } \\
\text { tailed) }\end{array}$} & Pembelajaran Bahasa Indonesia & . & .000 \\
\hline & Minat Membaca Siswa & .000 & \\
\hline \multirow[t]{2}{*}{$\mathrm{N}$} & Pembelajaran Bahasa Indonesia & 46 & 46 \\
\hline & Minat Membaca Siswa & 46 & 46 \\
\hline
\end{tabular}

Terdapat corelasi atau hubungan antara dua variabel tersebut, terlihat pada tabel diatas.

\begin{tabular}{|c|c|c|c|}
\hline \multicolumn{4}{|c|}{ Variables Entered/Removed $^{\mathrm{a}}$} \\
\hline Model & Variables Entered & Variables Removed & Method \\
\hline 1 & Minat Membaca Siswa ${ }^{b}$ & & Enter \\
\hline
\end{tabular}

\begin{tabular}{|c|c|c|c|c|c|c|c|c|c|}
\hline \multicolumn{10}{|c|}{ Model Summaryb } \\
\hline & & & & & & Cha & e Sta & & \\
\hline Model & $\mathrm{R}$ & $\begin{array}{c}R \\
\text { Square }\end{array}$ & $\begin{array}{l}\text { Adjusted R } \\
\text { Square }\end{array}$ & $\begin{array}{l}\text { Std. Error of } \\
\text { the Estimate }\end{array}$ & $\begin{array}{l}\text { R Square } \\
\text { Change }\end{array}$ & $\begin{array}{c}\mathrm{F} \\
\text { Change }\end{array}$ & df1 & df2 & $\begin{array}{l}\text { Sig. F } \\
\text { Change }\end{array}$ \\
\hline 1 & $.828^{\mathrm{a}}$ & .686 & .679 & 1.040 & .686 & 96.070 & 1 & 44 & .000 \\
\hline
\end{tabular}

a. Predictors: (Constant), Minat Membaca Siswa

Dari tabel model summary di atas dapat dianalisis, sebagai berikut:

1. Menunjukkan bahwa hubungan (korelasi) antara minat membaca siswa dengan pembelajaran bahasa Indonesia sangat kuat positif, yaitu $r=0,828$. Arti positif adalah hubungan antara variabel $\mathrm{X}$ dan $\mathrm{Y}$ searah. Maksud searah disini, semakin tinggi minat membaca siswa, maka semakin meningkat hasil prestasi pembelajaran bahasa Indonesia. Begitu juga sebaliknya, semakin rendah minat membaca siswa, maka semakin menurun hasil prestasi belajar bahasa Indonesia.

2. Koefisien diterminasi $\left(\mathrm{R}^{2}\right)=0,686$ menunjukkan bahwa minat membaca berpengaruh terhadap prestasi belajar bahasa Indonesia sebesar 68\% sedangkan $32 \%$ yang lain dipengaruhi oleh faktor lain yang tidak diteliti.

\section{ANOVA $^{\mathrm{a}}$}


STAINU Purworejo: Jurnal As Sibyan

Jurnal Kajian Kritis Pendidikan Islam

Vol 4 No 1 Januari - Juni 2021

dan Manajemen Pendidikan Dasar

Homepage: https://ejournal.stainupwr.ac.id/

Email: sibyan.stainupwrj@gmail.com

E-ISSN: : 2599-2732

\begin{tabular}{lll|r|r|r|r}
\multirow{2}{*}{ Model } & \multicolumn{2}{c}{$\begin{array}{c}\text { Sum of } \\
\text { Squares }\end{array}$} & df & Mean Square & \multicolumn{1}{c}{$\mathrm{F}$} & \multicolumn{1}{c}{ Sig. } \\
\hline \multirow{2}{*}{1} & Regression & 103.895 & 1 & 103.895 & 96.070 & $.000^{\mathrm{b}}$ \\
\cline { 2 - 8 } & Residual & 47.584 & 44 & 1.081 & & \\
\cline { 2 - 8 } & Total & 151.478 & 45 & & & \\
\hline
\end{tabular}

a. Dependent Variable: Pembelajaran Bahasa Indonesia

b. Predictors: (Constant), Minat Membaca Siswa

Dari hasil tabel Anova berikut, maka dapat dianalisis sebagai berikut:

1. Membuat hipotesis dalam uraian kalimat

Ho : Model regresi sederhana tidak dapat digunakan untuk mengukur minat membaca siswa dengan prestasi Pembelajaran bahasa Indonesia.

Ha : Model regresi sederhana dapat digunakan untuk mengukur minat membaca siswa dengan prestasi pembelajaran bahasa Indonesia

2. Kaidah pengujian

a. Berdasarkan perbandingan antara $\mathrm{F}_{\text {hitung }}$ dan $\mathrm{F}_{\text {tabel }}$

Jika : $\mathrm{F}_{\text {hitung }} \leq \mathrm{F}_{\text {tabel }}$ maka Ho diterima

Jika : $\mathrm{F}_{\text {hitung }}>\mathrm{F}_{\text {tabel }}$ maka Ho ditolak.

Dimana:

Nilai $\mathrm{F}_{\text {hitung }}$ dari tabel anova sebesar 96,070 dan nilai $\mathrm{F}_{\text {tabel }}$ dari Tabel $\mathrm{F}=$ 2,2

Dengan diperoleh nilai $\mathrm{F}_{\text {tabel }}=\mathrm{F}_{a}(1, \mathrm{n}-2)$

$$
\begin{aligned}
& =\mathrm{F}_{(0,05)}(1,46-2) \\
& =\mathrm{F}_{(0,05)}(44) \\
& =2,2
\end{aligned}
$$

Maka dari hasil tersebut, maka $\mathrm{F}_{\text {hitung }}>\mathrm{F}_{\text {tabel }}=96,070>2$, , maka Ho ditolak dan Ha diterima.

Jadi, dapat diambil kesimpulan bahwa Model Regresi Linear sederhana dapat digunakan untuk mengukur minat membaca siswa mempunyai pengaruh terhadap prestasi belajar bahasa Indonesia. 
STAINU Purworejo: Jurnal As Sibyan Jurnal Kajian Kritis Pendidikan Islam

\section{dan Manajemen Pendidikan Dasar}

Homepage: https://ejournal.stainupwr.ac.id/

Email: sibyan.stainupwrj@gmail.com

E-ISSN: : 2599-2732

\begin{tabular}{|c|c|c|c|c|c|c|c|c|}
\hline \multicolumn{9}{|c|}{ Coefficients $^{a}$} \\
\hline & & \multicolumn{2}{|c|}{$\begin{array}{l}\text { Unstandardized } \\
\text { Coefficients }\end{array}$} & \multirow{2}{*}{$\begin{array}{c}\text { Standardi } \\
\text { zed } \\
\text { Coefficients } \\
\text { Beta }\end{array}$} & \multirow[b]{2}{*}{$t$} & \multirow[b]{2}{*}{ Sig. } & \multicolumn{2}{|c|}{$\begin{array}{l}\text { 95.0\% Confidence } \\
\text { Interval for B }\end{array}$} \\
\hline Model & & $\mathrm{B}$ & $\begin{array}{l}\text { Std. } \\
\text { Error }\end{array}$ & & & & $\begin{array}{l}\text { Lower } \\
\text { Bound }\end{array}$ & $\begin{array}{l}\text { Upper } \\
\text { Bound }\end{array}$ \\
\hline 1 & (Constant) & -.249 & 1.616 & & -.154 & .878 & -3.507 & 3.008 \\
\hline & $\begin{array}{l}\text { Minat Membaca } \\
\text { Siswa }\end{array}$ & .340 & .035 & .828 & 9.802 & .000 & .270 & .410 \\
\hline
\end{tabular}

a. Dependent Variable: Pembelajaran Bahasa Indonesia

\section{Residuals Statistics ${ }^{a}$}

\begin{tabular}{l|r|r|r|r|r} 
& Minimum & Maximum & Mean & Std. Deviation & N \\
\hline Predicted Value & 12.33 & 18.11 & 15.52 & 1.519 & 46 \\
\hline Residual & -2.709 & 1.631 & .000 & 1.028 & 46 \\
\hline Std. Predicted Value & -2.101 & 1.702 & .000 & 1.000 & 46 \\
\hline Std. Residual & -2.605 & 1.569 & .000 & .989 & 46 \\
\hline
\end{tabular}

a. Dependent Variable: Pembelajaran Bahasa Indonesia

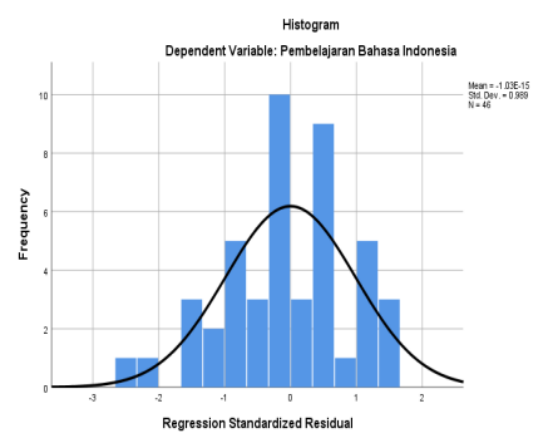

b. Berdasarkan Uji T

Langkah-langkahnya:

1) Membuat hipotesis dalam bentuk kalimat

$\mathrm{H}_{\mathrm{o}}$ : Tidak terdapat pengaruh antara minat membaca dengan prestasi

belajar Bahasa Indonesia

$\mathrm{H}_{\mathrm{a}}$ : Terdapat pengaruh antara minat membaca dengan prestasi Belajar

Bahasa Indonesia

2) Kaidah Pengujian

Jika, $-\mathrm{t}_{\text {tabel }} \leq \mathrm{t}_{\text {hitung }} \leq \mathrm{t}_{\text {tabel }}$, maka $\mathrm{H}_{\mathrm{o}}$ diterima 
STAINU Purworejo: Jurnal As Sibyan Jurnal Kajian Kritis Pendidikan Islam

dan Manajemen Pendidikan Dasar

Homepage: https://ejournal.stainupwr.ac.id/

Email: sibyan.stainupwrj@gmail.com

E-ISSN: : 2599-2732

Jika, $\mathrm{t}_{\text {hitung }} \geq \mathrm{t}_{\text {tabel }}$ maka $\mathrm{H}_{\mathrm{o}}$ ditolak.

Dari tabel Coefficients ${ }^{\mathrm{a}}$ diperoleh nilat $\mathrm{t}_{\text {hitung }}=9,802$

Nilai $\mathrm{t}_{\text {tabel }}=\mathrm{t}_{(\mathrm{a} / 2)(\mathrm{n}-2)}$

$$
\begin{aligned}
& =\mathrm{t}_{(0,05 / 2)(46-2)} \\
& =\mathrm{t}_{(0.025)(44)} \\
& =2,000
\end{aligned}
$$

Nilai $t_{\text {tabel }}$ dapat dilihat pada tabel di bawah ini:

Tabel 21

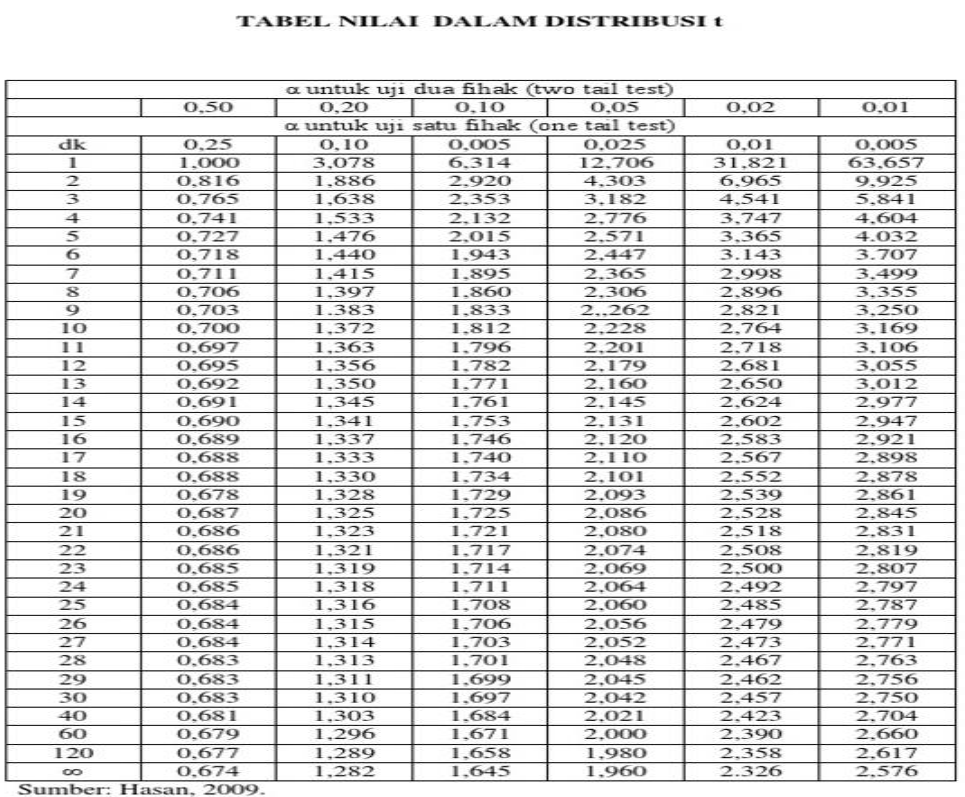

3) Membandingkan $t_{\text {tabel }}$ dan $t_{\text {hitung }}$

Ternyata $\mathrm{t}_{\text {hitung }}=9,802>\mathrm{t}_{\text {tabel }}=2,000$, maka $\mathrm{H}_{\mathrm{o}}$ ditolak.

4) Membuat Keputusan

Dari Penghitungan di atas, maka dapat diambil kesimpulan bahwa terdapat pengaruh antara minat membaca siswa dengan prestasi belajar Bahasa Indonesia.

\section{Interprestasi Data}


Dari hasil perhitungan nilai variabel minat membaca adalah kategori sangat tinggi. Sedangkan perhitungan rata-rata pembelajaran bahasa Indonesia dalam kategori sangat tinggi pula. Hal ini berarti bahwa minat membaca sudah sangat baik. Sementara, dalam uji regresi linear sederhana, Uji Normalitas, Uji Linieritas dan Uji Signifikan, Korelasi Produk moment dapat diketahui bahwa pengaruh minat membaca siswa dengan prestasi belajar bahasa Indonesia di MIN 3 Purworejo dapat dibuktikan dengan kriteria pengujian Ho yaitu Ho diterima jika Fhitung < Ftabel dan sedangkan hasil penelitian membuktikan Fhitung $>$ Ftabel $=96,070>2,2$, maka Ho ditolak dan Ha diterima, dengan thitung = 9,802 dan ttabel = 2,00, Uji Normalitas $=0,200>$ nilai kritisnya $=0,198$ dan rhitung $=0,828>$ rtabel $=0,297$ dengann taraf signifikansi 5\%. Dilihat dari hasil penelitian yang telah penulis lakukan pada kelas III di MIN 3 Purworejo, tentang "Pengaruh Minat Membaca Siswa terhadap Prestasi Belajar Bahasa Indonesia di MIN 3 Purworejo", maka hipotesis nol yang berbunyi tidak terdapat pengaruh yang positif, signifikan dan linear antara $\mathrm{X}$ dan $\mathrm{Y}$, ditolak, sebaliknya hipotesis alternative yang berbunyi “terdapat pengaruh yang positif, signifikan dan linear antara variabel $\mathrm{X}$ dan variabl Y”, diterima.

Dengan demikian dapat dikatakan bahwa minat membaca siswa terbukti merupakan predictor yang ikut menentukan prestasi belajar bahasa Indonesia di MIN 3 Purworejo. Sehingga semakin tingggi minat membaca siswa, maka semakin tinggi pula prestasi belajar bahasa Indonesia di kelas III MIN 3 Purworejo. Hal ini ditunjukkan dengan persamaan garis regresi yaitu $\mathrm{Y}=0,21+0,33 \mathrm{X}$. Dengan demikian dapat diketahui bahwa minat membaca siswa berpengaruh terhadap prestasi belajar bahasa Indonesia di kelas III MIN 3 Purworejo.

\section{KESIMPULAN}

Berdasarkan hasil analisis data yang dilakukan tentang pengaruh minat membaca siswa terhadap prestasi belajar Bahasa Indonesia siswa di MIN 3 Purworejo, maka dapat diambil kesimpulan sebagai berikut: 
STAINU Purworejo: Jurnal As Sibyan

Jurnal Kajian Kritis Pendidikan Islam

Vol 4 No 1 Januari - Juni 2021

dan Manajemen Pendidikan Dasar

Homepage: https://ejournal.stainupwr.ac.id/

Email: sibyan.stainupwrj@gmail.com

E-ISSN: : 2599-2732

a. Hasil penghitungan korelasi Product Moment Pearson menunjukkan bahwa rhitung $=0,828>r_{\text {tabel }}=0,297$ dengan taraf signifikansi $5 \%$ berarti minat baca memiliki hubungan yang kuat dengan prestasi belajar Bahasa Indonesia.

b. Hasil penghitungan $t$-test menunjukkan bahwa $t_{\text {hitung }}=9,802>t_{\text {tabel }}=2,000$, dengan taraf signifikansi $5 \%$ berarti minat baca memiliki pengaruh yang signifikansi terhadap prestasi belajar Bahasa Indonesia

c. Hasil perhitungan uji $\mathrm{F}$ diperoleh $F_{\text {hitung }}$ sebesar 6,070 dan $F_{\text {tabel }}$ sebesar 2,2 dengan taraf signifikansi 5\%. Maka dapat diambil kesimpulan bahwa $F_{\text {hitung }} 96,070>F_{\text {tabel }}$ 2,2 maka $\mathrm{H}_{\mathrm{o}}$ ditolak dan $\mathrm{H}_{\mathrm{a}}$ diterima. Dengan demikian, hipotesis alternatif yang menyatakan "Terdapat pengaruh yang signifikan minat membaca siswa terhadap belajar Bahasa Indonesia Siswa" diterima.

d. Koefisien diterminasi $\left(\mathrm{R}^{2}\right)=0,686$ menunjukkan bahwa minat membaca berpengaruh terhadap prestasi belajar bahasa Indonesia sebesar $68 \%$ sedangkan $32 \%$ yang lain dipengaruhi oleh faktor lain yang tidak diteliti.

\section{DAFTAR PUSTAKA}

Abiding, Yunus, Pembelajaran Bahasa Indonesia Berbasis Pendidikan Karakter, Bandung: Refika Aditama, 2012.

BSNP, Standar Isi Untuk Satuan Pendidikan Dasar dan Menengah, Jakarta: BSNP, 2006.

Dalman, Ketrampilan Membaca, Jakarta: Rajawali Pers, 2014.

Departemen Pendidikan Nasional, Kamus Besar Bahasa Indonesia, P.T. Gramedia Pustaka Utama, 2008.

Djago, Tarigan, Pendidikan Bahasa dan Sastra Indonesia di Kelas REndah, Jakarta: Universitas Terbuka, 2002.

Harras, dkk, Membaca I, Jakarta: Departemen Pendidikan dan Kebudayaan, 1997. Kamus Besar Bahasa Indonesia, Departemen Pendidikan Nasional, 1995. 
STAINU Purworejo: Jurnal As Sibyan

Jurnal Kajian Kritis Pendidikan Islam

Vol 4 No 1 Januari - Juni 2021

dan Manajemen Pendidikan Dasar

Homepage: https://ejournal.stainupwr.ac.id/

Email: sibyan.stainupwrj@gmail.com

E-ISSN: : 2599-2732

Martini, Nina Aryani, Peranan Keluarga dalam Menumbuhkan Minat Baca Anak,

Simposium Peran Serta Perpustakaan dalam Upaya Membangun Keluarga

Sejahtera, Jakarta: Perpustakaan Umum Jakarta Pusat, 1995.

Masduki, S, Perpustakaan Sekolah Sebagai Sumber Pengembangan Minat dan

Kegemaran Membaca, dalam Departemen Pendidikan dan Kebudayaan, Laporan

Lokakarya Pengembangan Minat dan Kegemaran Membaca, Jakarta: Departemen

Pendidikan dan Kebudayaan, 1997.

Nur, Samsiyah, Pembelajaran Bahasa Indonesia di SD Kelas Tinggi, Jawa Timur:

CV. AE MEDIA GRAFIKA, 2016.

Oemar, Hamalik, Proses Belajar Mengajar, Jakarta: PT. Bumi Aksara, 2008.

Periantalo, Jelpa, Penelitian Kuantitatif Untuk Psikologi, Yogyakarta: Pustaka Pelajar, 2016.

S. Akhadiah, Pembinaan Kemampuan Menulis Bahasa Indonesia, Jakarta: Erlangga, 1999.

Sabarti, Akhadiah, Pedoman Pelaksanaan Pembelajaran Membaca di SD, Materi Ajar PGSD FIP UNJ, 1993.

Sardiman, Interaksi dan Motivasi Belajar Mengajar, Jakarta: Raja Grafindo Persada, 2011.

Sandjaja, Soejanto, Pengaruh Keterlibatan Orang Tua Terhadap Minat Membaca Anak Ditinjau dari Pendekatan Stres Lingkungan, dalam Jurnal Online, Malang: Fakultas Ekonomi dan Bisnis. Brawijaya, 2012.

Slameto, Belajar dan faktor-faktor Yang Mempengaruhinya, Jakarta: Rineka Cipata, 2013.

Sudarsana, dkk, Pembinaan Minat Baca, Jakarta: Universitas Terbuka, 2010.

Sulistyorini\&Muhammad Fathurrahman, Belajar dan Pembelajaran, Yogyakarta:

Teras, 2012.

Syah, Muhibbin, Psikologi Pendidikan, Bandung: Remaja Rossdakarya, 2004. 
Syaiful Bahri, Djamarah, Prestasi Belajar dan Kompetensi Guru, Surabaya: Usaha Nasional, 1994.

Syofian, Siregar, Statistik Parametrik Untuk Penelitian Kuantitatif, Jakarta: Bumi Aksara, 2017.

T.L, Gie, Terampil Menulis, Yogyakarta: Andi Offset, 2002.

Tampubolon, D.P, Mengembangkan Minat dan Kebiasaan Membaca Pada Anak, Bandung: Angkasa, 1993.

Tim Penyusun, Kamus Besar Bahasa Indonesia, Jakarta: Balai Pustaka, 2000.

Wahadaniyah, Herman, Perpustakaan Sekolah Sebagai Sarana Pengembangan Minat dan Kegemaran Membaca dalam Departemen Pendidikan dan Kebudayaan Laporan Lokakarya Pengembangan Minat dan Kegemaran Membaca, Jakarta: Departemen Pendidikan dan Kebudayaan, 1997.

Wawancara dengan Bapak Kholilurrohman, tanggal 13 Oktober 2020 di kantor MIN 3 Purworejo.

Wawancara dengan Bapak Kosim dan Ibu Sri Rezeki, tanggal 20 November dan 15 Oktober 2020 di kantor dan di UKS MIN 3 Purworejo.

WJS, Purwodarminto, Kamus Besar Bahasa Indonesia, Jakarta: Balai Pustaka, 1989.

Zaenal, Arifin, Evaluasi Pembelajaran, Jakarta: Dirjen Pendidikan Islam, Depag, 2009. 